\title{
Analyze of Employe's Motivation Factor in Sekretariat Daerah in Kabupaten Bengkulu Utara
}

\section{Analisis Faktor Motivasi Kerja Pada Sekretariat Daerah Kabupaten Bengkulu Utara}

\author{
Marsidi 1); Askani 2) \\ 1,2) Sekolah Tinggi Ilmu Administrasi Bengkulu \\ Email: ${ }^{1)}$ marsidi0459@gmail.com; ${ }^{2)}$ askanistia1@gmail.com
}

How to Cite :

Marsidi., Askani. (2022). Analyze of Employe's Motivation Factor in Sekretariat Daerah in Kabupaten Bengkulu Utara. Jurnal Ekonomi Manajemen Akuntansi Dan Keuangan, 3(1). DOI: https://doi.org/10.53697/emak.v3i1

ARTICLE HISTORY

Received [22 Desember 2021]

Revised [29 Desember 2021]

Accepted [05 Januari 2022]

\section{KEYWORDS}

Motivation, Motivation Factor,

Motivation's Effort

This is an open access article under the $C C-B Y$-SA license

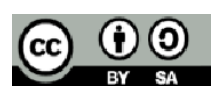

\section{ABSTRAK}

Penelitian ini bertujuan untuk mendeskripsikan motivasi kerja pegawai pegawai di Sekretariat Daerah Kabupaten Bengkulu Utara. jumlah responden/informan yang meliputi Kabag 2 Orang, Kasubbag 10 orang dan Staff 13 orang. Metode data dilakukan dengan wawancara dan kuesioner, metode analisis data adalah deskriptif kualitatif. Penelitiannya menggunakan berdasarkan hasil penelitian, maka faktor motivasi yang paling penting adalah kebutuhan akan gengsi dan sebenarnya yang membuat seorang Pegawai merasa percaya diri untuk melakukan suatu pekerjaan/pekerjaan suatu usaha, yang telah dilakukan oleh pemberi kerja untuk memotivasi. Pegawai memiliki komunikasi yang baik dengan kata-kata yang sesuai.

\section{ABSTRACT}

This study aims to describe the work motivation of employees at the Regional Secretariat of North Bengkulu Regency. the number of respondents/informants which includes Head of Division 2 people, Head of Subsection 10 people and Staff 13 people. The data method was carried out by interviews and questionnaires, the method of data analysis was descriptive qualitative. The research uses based on research results, the most important motivational factor is the need for prestige and actually what makes an employee feel confident to do a job / work of a business, which has been done by the employer to motivate. Employees have good communication with appropriate words.

\section{PENDAHULUAN}

Kehidupan organsisasional bahwa pimpinan memainkan peranan yang sangat penting, bahkan dapat dikatakan sangat menentukan dalam usaha pencapaian tujuan yang telah ditetapkan sebelumnya. Memang benar bahwa pimpinan, baik secara individual maupun sebagai kelompok, tidak mungkin dapat bekerja sendirian. Pimpinan membutuhkan sekelompok orang lain, yang dengan istilah populer dikenal sebagai bawahan, yang digerakkan sedemikian rupa sehingga para bawahan itu memberikan pengabdian dan sumbangsihnya kepada organisasi, terutama dalam cara bekerja yang efisien, efektif, ekonomis dan produktif.

Seorang pimpinan harus mampu menciptakan suasana yang kondusif, memberikan cukup perhatian, memberikan penghargaan terhadap prestasi kerja, menjalin komunikasi yang baik dengan seluruh pegawai karena Pimpinan maupun Pegawai Negeri Sipil yang menjadi bawahannya, memerlukan komunikasi yang efektif diantara anggota-anggota kelompok. Untuk 
menciptakan kondisi demikian, diperlukan adanya usaha-usaha untuk meningkatkan kualitas dan kepuasan kerja bagi setiap pegawai. Ini dimungkinkan bila terwujudnya peningkatan motivasi kerja pegawai secara optimal. Demikian halnya yang menjadi permasalahan pada Bagian Pemerintahan di Sekretariat Daerah Kabupaten Bengkulu Utara saat ini, yaitu wewenang pimpinan yang begitu dominan terhadap masalah-masalah sumber daya manusia, keuangan serta pengembangan lainnya. Pimpinan dalam membagi-bagi tugas/pekerjaan didasari atas rasa pilih kasih, hanya terhadap pegawai/orang-orang tertentu, bukan berdasarkan tugas pokok dan fungsi yang ada. Hal ini akan menimbulkan sikap apatis, tidak bersemangat, ragu-ragu dan takut salah, kecewa, masa bodoh, putus asa serta menjadikan kegiatan yang ada tidak berjalan sebagaimana mestinya.

\section{LANDASAN TEORI}

\section{Pengertian Motivasi}

Motivasi berasl dari motive atau dengan bahasa latinya, yaitu movere, yang berarti "mengarahkan". Pengertian motivasi kerja menurut Hasibuan (2016), adalah sejumlah aktivitas fisik dan mental untuk mengerjakan suatu pekerjaan. Berdasarkan urian tersebut dapat dilihat bahwa tingkat motivasi hanya bisa diukur secara kualitatif. la hanya bisa dilihat dari perilaku yang ditampilkan oleh para Pegawai. Bila seorang sering absen, apatis, agresif, tidak loyal, frustasi, berpikir reaktif atau berperilaku negatif lainnya, maka sering ia disebut sebagai Pegawai bermotivasi rendah. Secara kuantitatif, sulit menentukan apakah seorang Pegawai mempunyai motivasi rendah atau tinggi, tetapi dari konstruk perilakunya orang akan gampang menilai.

\section{Aspek, Pola dan Tujuan Motivasi}

Keinginan dan kegairahan kerja dapat ditingkatkan berdasarkan pertimbangan tentang adanya 2 (dua) aspek motivasi yang bersifat statis, yaitu: 1) Aspek motivasi statis tampak sebagai keinginan dan kebutuhan pokok manusia yang menjadi dasar dan harapan yang akan dipeolehnya dengan tercapainya tujuan organisai; dan 2) Aspek motivasi statis adalah berupa alat peransang/insentif yang diharapkan akan dapat memenuhi apa yang menjadi keinginan dan kebutuhan pokok yang diharapkannya tersebut. Sedangkan pola motivasi menurut David Mc. Clelland dalam Hisibuan (2016 :97) adalah: a) Achievement Motivation; b) Affiliation Motivation; c) Competence Motivation; d) Power Motivation

Adapun tujuan pemberian motivasi menurut Hasibuan (2016: 98) adalah sebagai berikut tiga diantaranya: a) Mendorong gairah dan semangat kerja karayawan; b) Meningkatkan Moral dan Kepuasan kerja Pegawai; d) Meningkatkan Produktivitas Kerja Pegawai,

\section{Alat dan Jenis Motivasi}

Berdasarkan penelitian terdahulu alat-alat yang digunakan dalam motivasi adalah material insentif, nonmaterial insentif, kombinasi material dan nonmaterial insentif.

\section{Metode Motivasi}

Metode-metode dalam motivasi menurut (Murray dalam Mangkunegara (2017) yaitu metode langsung (Direct Motivation) dan motivasi tidak langsung (Indirect Motivation).

\section{Pengukuran Motivasi Kerja}

Pengukuran motivasi kerja menurut Murray dalam Mangkunegara (2017), menyatakan bahwa pengukuran motivasi dapat dilakukan dengan melihat karakter orang sebagai berikut : a) Melakukan sesuatu dengan sebaik-baiknya; b) Kretif dan inovatif; c) Melakukan sesuatu untuk mencapai kesuksesan; d) Menyelesaikan tugas-tugas yang memerlukan usaha dan keterampilan; e) Selalu mencari sesuatu yang baru; f) Berkeinginan menjadi orang terkenal atau menguasai bidang 
tertentu; g) Melakukan pekerjaan yang sukar dengan hasil yang memuaskan; h) Inisatif kerja tinggi; i) Melakukan sesuatu yang lebih baik dari pada orang lain.

\section{Faktor- Faktor Yang Mendorong Motivasi}

Menurut Kuesioner Utama oleh Manolopoulos dalam Istijanto OEI (2010), menyatakan halhal yang memotivasi orang bekerja lebih baik adalah sebagai berikut: a) Pemberian Tunjangan, bonus; b) Komunikasi dan kerjasama antarbagian; c) Peluang karier yang lebih maju; d) Keamanan tempat kerja; e) Kondisi atau Fasilitas kerja; f) Peluang untuk mengembangkan keahlian individu; g) Kesempatan bekerja secara kreatif; h) Kebutuhan harga diri dan citra diri; i) Pengakuan kerja; j) Peluang untuk memiliki tanggung jawab sendiri; k) Kelangsungan kerja.

\section{Upaya-upaya memotivasi}

Beberapa cara atau upaya yang dapat dilakukan untuk meningkatkan motivasi Pegawai oleh (D2A002018_DIMAS ESTU HAPSORO) yang diambil dari data internet adalah sebagai berikut: a) Rasa Hormat (Respect); b) Informasi (Information); c) Perilaku (Behavior); d) Hukuman (Punishment); e) Perintah (Command); f) Perasaan (Sense).

\section{METODE PENELITIAN}

Penelitian ini menggunakan metode deskriftif kualitatif. Penelitian metode kualitatif ini memaparkan seluruh fakta dan peristiwa lapangan merupakan serangkaian penelitian yang mencoba untuk mengedepankan proses dengan harapan akan memperoleh hasil penelitian akurat dan bukan rekayasa semata. Proses yang dimaksud dalam penelitian ini adalah motivasi kerja pegawai (studi deskriptif kualitatif pada Sekretariat Daerah Kabupaten Bengkulu Utara).

\section{Analisis Deskriptif}

Suatu analisis yang dilakukan dengan cara mendeskripsikan atau menjelaskan berbagai temuan yang diperoleh saat penelitian yang disusun dalam bentuk tabel distribusi frekuensi.

\section{Analisis Kualitatif}

Teknik analisis data pada penelitian ini tentunya agar dapat melihat kondisi motivasi kerja pegawai di Sekretariat Daerah Kabupaten Bengkulu Utara. Tahapan- tahapan analisis data dimaksud adalah: 1. Analisis lapangan; dan 2. Analisis hasil yang dilakukan setelah data-data terkumpul. Analisa hasil ini dilakukan melalui 3 (tiga) tahapan yaitu: a. Reduksi Data; b. Penyajian (display data); c. Penarikan Kesimpulan (conclusion drawing).

\section{HASIL DAN PEMBAHASAN}

\section{Hasil Penelitian}

Pada Bagian ini peneliti akan menyajikan hasil penelitian yang telah dilakukan untuk mengetahui sejauh mana tingkat motivasi kerja Pegawai melalui Indikator Motivasi Kerja Pegawai di Sekretariat Daerah Kabupaten Bengkulu Utara.

Hasil Penelitian menunjukan bahwa rata-rata penilaian responden terhadap indikator motivasi yang dapat mengukur tingkat motivasi pegawai dilingkungan sekretariat daerah kabupaten Bengkulu Utara adalah berada pada kriteria Rendah dengan nilai rata-rata sebesar 2,54 (1,81-2,60). Hal ini menunjukan bahwa motivasi kerja pada Sekretariat Daerah Kabupaten Bengkulu Utara masih tergolong buruk yang tentunya akan mempengaruhi kualitas atau hasil kerja pegawai di Sekretariat Daerah Kabupaten Bengkulu Utara itu sendiri yang menandakan bahwa sangatlah diperlukan adanya suatu faktor motivasi yang dapat mendorong kerja pegawai tersebut.

Hasil rata-rata tertinggi pada indikator motivasi yang dapat mendorong motivasi pegawai sebesar 2,95(2,61 - 3,40) yang berarti berada pada kriteria sedang pada pernyataan "Saudara 
Melakukan Sesuatu untuk mencapai kesuksesan" yang dalam hal ini berarti bahwa pegawai di Sekretariat Daerah Bengkulu Utara itu belum termotivasi untuk melakukan sesuatu untuk mencapai kesuksesan meskipun pada kenyataanny ada sebagian pegawai yang mayoritas kecil melakukan sesuatu tugas dengan tujuan mencapai kesuksesan.

Dilihat dari rata-rata terendah pada Indikator motivasi yang dapat mendorong motivasi pegawai adalah sebesar 2,22 (1,80-2,60) yang berarti berada pada criteria Rendah pada pernyataan "Saudara Melakukan Sesuatu yang lebih baik dari pada orang lain" yang dalam hal ini berarti bahwa pegawai di Sekretariat Daerah Bengkulu Utara itu belum termotivasi untuk melakukan sesuatu yang lebih baik daripada yang lainnya dalam hal ini khususnya antar pegawai itu sendiri belum menunjukan hal yang melebihi pegawai yang lainnya satu sama lainnya .

\section{Mengevaluasi Faktor yang mempengaruhi Motivasi Kerja Pegawai :}

Dengan melihat angka indeks tertinggi sebagai urutan kepentingan Faktor yang memotivasi kerja pegawai maka urutan yang paling dipentingkan atau rangking 1 adalah pernyataan "kebutuhan harga diri dan citra diri", yang berarti Para pegawai membutuhkan kebutuhan harga diri dan citra diri yang dianggap dapat menambah kepercayaan diri pegawai itu tersendiri sehingga seorang pegawai merasa lebih mampu untuk mejalankan tugas yang telah diberikan kepadanya, diikuti pada rangking ke 2 pernyataan "komunikasi dan kerjasama antarbagian, peluang karier yang lebih maju; dan kondisi atau fasilitas kerja yang memadai pengakuan kerja" yaitu Komunikasi,kerjasama antar bagian, kondisi atau fasilitas kerja yang memadai dan peluang kerja lebih maju yang ketiga hal ini dianggap penting karena dengan adanya komunikasi yang baik maka akan terjalin saling kesinambungan dalam suatu proses kerja, serta dengan adanya fasilitas yang memadai tentu akan lebih menunjang proses kegiatan kerja, namun juga dengan melihat sisi peluang kerja yang lebih maju. Pernyataan "peluang untuk mengembangkan keahlian individu" pada rangking ke 3 yaitu Peluang untuk mengembangkan keahlian individu dalam hal ini pegawai menginginkan adanya suatu peluang atau bagian untuk melakukan dan mengembangkan keahlian individu pegawai itu sendiri, rangking ke 4 yaitu pertanyaan mengenai "kelangsungan kerja" kelangsungan kerja dan yang terakhir rangking ke 5 adalah pernyataan tentang "Pengakuan Kerja".

\section{Upaya- Upaya yang dilakukan untuk memotivasi Pegawai}

Upaya- upaya yang dilakukan untuk memotivasi pegawai di Sekretariat Daerah Kabupaten Bengkulu Utara, diantaranya : 1. Pemberian rasa hormat terhadap pegawai dari pimpinan serta dari organisasi itu sendiri terutama atas keberhasilan pegawainya; 2. Dalam bekerja sama yang baik antara pimpinan dan bawahan tentunya sangat diperlukan suatu informasi yang jelas untuk menghindari kesalahpahaman dan komunikasi yang simpang siur baik itu dari pimpinan kepada bawahan maupun dari bawahan kepada atasannya; 3. Pimpinan berhak memberikan teguran kepada bawahan atas prilaku yang kurang dianggap baik terutama ketika bawahan melakukan suatu kesalahan dan dianjurkan teguran itu sendiri bersifat lebih membangun; 4. Pada saat bawahan melakukan suatu kesalahan baik yang fatal maupun tidak, maka seorang pimpinan berhak memberikan hukuman yang setimpal terhadap kesalahan yang dibuat; 5. Untuk membangun kerjasama yang baik maka antar pimpinan dan bawahan sangat diperlukan adanya hubungan baik guna memperlancar proses dalam bekerja dan terciptanya suasana yang harmonis dalam melakukan suatu pekerjaan; 6 . Pada saat seorang bawahan memberikan hasil kerja terbaik yang patut untuk dibanggakan dan dicontohkan, maka ada baiknya sebagai seorang pimpinan memberikan suatu reward atau penghargaan. Dengan demikian bawahan tersebut akan terlihat lebih semangat dalam bekrja untuk mencapai tujuan kerja; 7. Melakukan suatu negosiasi kerja dalam hal ini antara pimpinan dan bawahan diadakannya suatu rapat kecil dilingkngan kerja suatu bagian tertentu guna mengetahui maksud dan tujuan dan tatacara alur kerja yang baik dalam memperlancar proses kerja, ini juga bertujuan sebagai wadah untuk menampung aspirasi dari para bawahan untuk mengevaluasi proses kerja yang telah berlangsung dan yang selanjutnya. 


\section{Pembahasan}

Berdasarkan data yang diperoleh dari penyebaran kuesioner, maka dapat diketahui variabel faktor motivasi kerja pegawai yang diukur melalui indikator motivasi itu sendiri adalah pada kondisi yang tergolong rata-rata kurang baik. Dapat dilihat rata-rata jawaban tertinggi responden sebesar $2,95(2,61$ - 3,40) untuk pertanyaan "Melakukan sesuatu pekerjaan untuk mencapai kesuksesan ", artinya nilai rata-rata jawaban adalah cukup baik yang memberi penegasan bahwa pegawai melakukan sesuatu pekerjaan untuk mencapai kesuksesan. Akan tetapi jika dilihat dari rata-rata jawaban terendah responden sebesar 2,22 $(1,81-2,60)=$ kurang baik untuk pertanyaan "Belum Melakukan Sesuatu Yang Lebih Baik Dari Orang Lain" artinya rata-rata jawaban tidak baik dikarenakan para bawahan belum termotivasi untuk lebih maju dari yang lainnya. Jika dihubungkan antara rata-rata jawaban tertinggi dan terendah maka dapat disimpulkan pegawai kurang termotivasi bekerja dengan pekerjaan selama ini.Pegawai masih kurang menjalankan suatu pekerjaan dengan semaksimal mungkin sehingga hal ini bisa menyebabkan kualitas kerja yang menurun dan kurang baik.

Dari hasil angka indeks yang telah dilakukan maka dapat disimpulkan bahwa yang terpenting adalah menjalin komunikasi yang baik antara atasan dan bawahan, membangun kerjasama yang baik untuk hasil yang lebih maksimal, memenuhi fasilitas-fasilitas atau fasilitas penunjang oprasional dalam bekerja agar lebih termotivasi bekerja para pegawainya serta kebutuhan akan harga diri dan citra diri yang dapat membangun kepercayaan diri seorang pegawai.

Upaya Motivasi yang dilakukan oleh pimpinan terhadap bawahannya adalah dengan yang terutama yaitu menjalin suatu komunikasi kerja yang baik, memberikan rasa hormat agar pegawai merasa dalam bekerja ia lebih dihargai, membangun informasi yang jelas agar tidak terjadi kesalahpahaman dalam penyampaian imformasinya, memberikan teguran atau tindakan terhadap pegawai yang melakukan suatu kesalahan namun masih dalam pemberian hukuman atau tindakan yang sewajarnya. Memberikan reward atau penghargaan kepada pegawai atau bawahan dalam keberhasilan kerjanya agar lebih bersemangat dalam bekerja dan melakukan suatu rapat kecil dalam bagian itu sendiri untuk menampung aspirasi atau masukan dari masing- masing bawahan tentang pelaksanaan kerja kedepannya.

Selanjutnya, dari hasil penelitian dapat diketahui bahwa faktor motivasi memiliki pengaruh yang paling tinggi terhadap motivasi kerja di lingkungan Sekterariat Daerah Kabupaten Bengkulu Utara. Dari hasil wawancara juga dapat diketahui bahwa hal yang sebenarnya dapat memotivasi kerja pegawai itu sendiri adalah berasal dari dirinya sendiri dan dengan sedikit dorongan seperti memberikan penghargaan atas apa yang telah dilakukan oleh bawahan dalam hal ini lebih bersifat ekonomis seperti adanya pemberian bonus atau tunjangan terhadao bawahan. Hal ini sejalan dengan pendapat yang dikemukakan oleh Robert (dalam Timple, 2002) faktor internal yang menyenangkan menjadi kunci pendorong pegawai untuk menghasilkan motivasi kerja yang tinggi.

Dari hasil wawancara yang telah dilakukan kepada 2 orang Kepala Bagian maka ditarik suatu kesamaan jawaban bahwa komunikasi yang baik serta kerjasama sangatlah diperlukan dalam mencapai hasil kerja bersama dalam hal ini khususnya pada tiap-tiap bagian untuk mencapai hasil yang baik dan mampu saling membangun motivasi karena berdasarkan hasil wawancara ini juga pimpinan menilai bahwa bawahannya masih kurang termotivasi dalam bekerja sehingga menyebabkan kualitas kerja yang menurun juga.

Dari hasil wawancara terhadap 10 orang Kasubbag dapat disimpulkan bahwa sampai saat ini para kasubbag melihat dan mengamati para stafny masih kurang termotivasi dalam bekerja dan dari tiap-tiap jawaban diketahui bahwa fasilitas penunjang sangatlah penting dalam memotivasi kerja pegawainya.

Selanjutnya hasil wawancara dari 13 orang staf bahwa komunikasi dan kerjasama yang baik antarbagian itu sangatlah penting. Pemberian bonus atau tunjangan dalam bekerja juga merupakan faktor pendukung dalam bekerja karena dengan adanya bonus yang berarti menambah kebutuhan ekonomi maka dirasa sangatlah perlu dalam pemenuhan kebutuhan sehari-hari. Kondisi dan Fasilitas penunjang kerja saat ini masih sirasa dalam kategori cukup bahkan sebagian menyatakan 
kurang memadai dalam hal ini tentu harus dipenuhi agar nantinya memotivasi kerja pegawai itu sendiri serta Jaminan keamanan kerja yang masih harus ditingkatkan lagi.

\section{KESIMPULAN DAN SARAN}

\section{Kesimpulan}

1. Hasil penelitian, motivasi kerja pegawai di Sekretariat Daerah Kabupaten Bengkulu Utara masuk dalam kategori kurang baik yang berarti masih kurangnya motivasi pegawai yang menjadi pokok permasalahannya. Para pegawai masih belum melakukan suatu pekerjaan yang lebih baik dari yang lainnya itu berarti bahwa motivasi atau kesadaran kerja untuk melakukan yang terbaik dalam bekerja yang dimiliki tiap-tiap pegawai masih sangat rendah dan masih harus ditingkatkan lagi agar tercapai hasil kerja yang memuaskan.

2. Tingkat Kepentingan Faktor yang memotivasi Pegawai di Sekretariat Daerah Bengkulu Utara adalah yang terpenting pegawai menginginkan kebutuhan harga diri dan citra diri yang membuat seorang pegawai merasa percaya diri untuk melakukan suatu pekerjaan sebagai mana mestinya dan sebaik-baiknya, Fasilitas kerja yang memadai dalam oprasional kerja, serta menjalin kerjasama dan komunikasi yang baik antarbagian agar tercapai tujuan kerja bersama.

3. Upaya- upaya yang dilakukan oleh atasan kepada bawahannya yang terutama menjalin komunikasi yang baik agar tidak terjadi kesalahpahaman, menjalin hubungan yang baik, memberikan peluang kerja kepada bawahan dengan baik, memberikan rasa hormat terhadap pegawai terutama terhadap hasil kerja atau prestasi kerja pegawai itu sendiri, pada saat bawahan melakukan suatu kesalahan, seorang pimpinan selayaknya memberikan teguran yang bersifat membangun agar sang pegawai juga merasa bahwa atasannya juga memiliki perhatian yang lebih, memberikan reward atas keberhasilan pegawai dalam mencapai tujuan kerjanya, melakukan negosiasi kerja yang berupa rapat kecil antar orang didalam suatu bagian untuk menampung informasi dan masukan baik dari bawahan ke atasan maupun atasan kepada bawahan.

\section{Saran}

1. Untuk meningkatkan faktor motivasi adalah dengan cara memberikan motivasi agar para staf dapat bekerja lebih baik daripada yang lainnya yang memicu suatu semangat untuk mencapai kerja yang lebih sempurna dan lebih menganggap bahwa keberadaan staf itu juga sangat berarti dalam hal ini yang dimaksud adalah adanya pengakuan kerja.

2. Untuk meningkatkan motivasi kerja pegawai adalah dengan cara menjalin komunikasi yang baik agar dalam bekerja tidak terjadi kesalahpahaman dalam pelaksanaan kerjanya serta agar terbinanya hubungan yang lebih harmonis antara staf dan atasannya serta dengan memenuhi kebutuhan akan fasilitas kerja yang memadai, menjamin keamanan dalam bekerja

\section{DAFTAR PUSTAKA}

Fahmi, I. (2012). Manajemen Teori, Kasus, dan Solusi. Bandung: Alfabeta.

Hasibuan, Melayu SP, 2016. Manajemen Sumber Daya Manusia, Edisi Revisi Bumi Aksara, Jakarta.

Mangkunegara, AP. 2017. Manajemen Sumber Daya Manusia. Cetakan Pertama, Rosda, Bandung.

Siagian, S. P. (2004). Teori Motivasi dan Aplikasinya. Jakarta: Rineka Cipta.

Sugiyono, 2009, Statistika untuk Penelitian, Bandung : CV Alfabeta.

Tella, Adeyinka, 2007, Work Motivation, Job Satisfaction, and Organisational Commitment of Library Personnel in Academic and Research Libraries in Oyo State, Nigeria, Library Philosophy and Practice 2007 (April). 